\title{
特許行政の最近の動向
}

特許庁 ${ }^{* 1}$ 特許審査第三部プラスチック工学 冨 士 良 宏*2

\section{Recent Developments in Patent Administration}

Yoshihiro Fuji ${ }^{* 2}$

Japan Patent Office*1

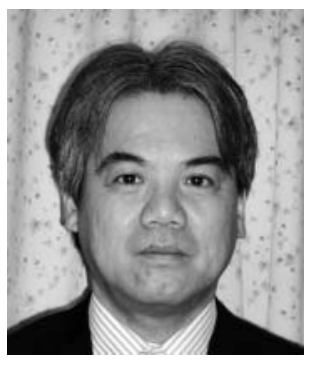

\begin{abstract}
In this report, the recent developments in patent administration are briefly explained, based on the author's presentation given at the annual meeting between the Japan Technical Association of the Pulp and Paper Industry (TAPPI) and the Japan Patent Office (JPO) in February 2012. The report focuses on the current status of patent applications and examinations in Japan, the recent trend of patent applications in the world, and the JPO's user-friendly programs to meet the applicants'diversified demands, in particular for their globalized intellectual property activities.

The number of patent applications of Japanese applicants in Japan has declined in the late 2000's. However, the expenditure on R\&D in Japan has gradually risen. It seems that the Japanese applicants have continuously made their efforts to develop new technologies, despite the economic downturn of Japan. Moreover, the global application rate and the number of PCT applications have been going up. It is assumed that they have turned their attentions towards the global market.

The JPO has offered a lot of user-friendly programs, in particular to encourage the Japanese applicants to compete in the globalized business fields. The JPO launched the Patent Prosecution Highway (PPH) with the United States Patent and Trademark Office (USPTO) in 2006 and has established the PPH network with 19 Patent Offices until February 2012. In addition, the JPO is now designing the global IP initiatives in order to guarantee that the Japanese applicants can expeditiously obtain secured patent rights all over the world.

It is expected that the report will help the members of the TAPPI design their own patent strategies and promote their international competitiveness.
\end{abstract}

分類 : $Z_{0}$ その他

\section{1.はじめに}

紙パルプ技術協会及び会員の皆様，毎年，特許庁プラス チック工学との意見交換の機会を与えていただき，ありが とうございます。特許庁プラスチック工学では, 文字通り プラスチックの成型・加工に関する技術のほか, 繊維, 積 層体，そして紙パルプなどに関する技術についての出願を

\footnotetext{
*1 テ100-8915 東京都千代田区霞が関 3-4-3/3-4-3

Kasumigaseki, Chiyoda-ku, Tokyo 100-8915, Japan

${ }^{* 2} \mathrm{E}-$ mail : fuji-yoshihiro@jpo.go.jp
}

審査しています。紙パルプ技術協会の会員企業は我々にと っての大事な顧客であり, 皆様と普段からコミュニケーシ ヨンを図ることが重要であると考えます。

今年度も 2 月 6 日に会が開かれ，非常に活発な情報交換 と議論が展開されましたが，その中から，当方がプレゼン テーションを行った「特許行政の最近の動向」について誌 面を借りてご紹介させていただきます。我が国及び世界の 特許出願・審査の現状やそれを背景とした我々の取組につ いてご理解いただき，知財戦略にご活用いただくと共に， 最も重要な課題であるグローバル化に対して今後どのよう に取り組むべきか，意識を共用していただくことがねらい 
○我が国への出願は、35万件前後で推移(2009年、2010年)。

○ 我が国の総R\&D費は、2010年に減少。
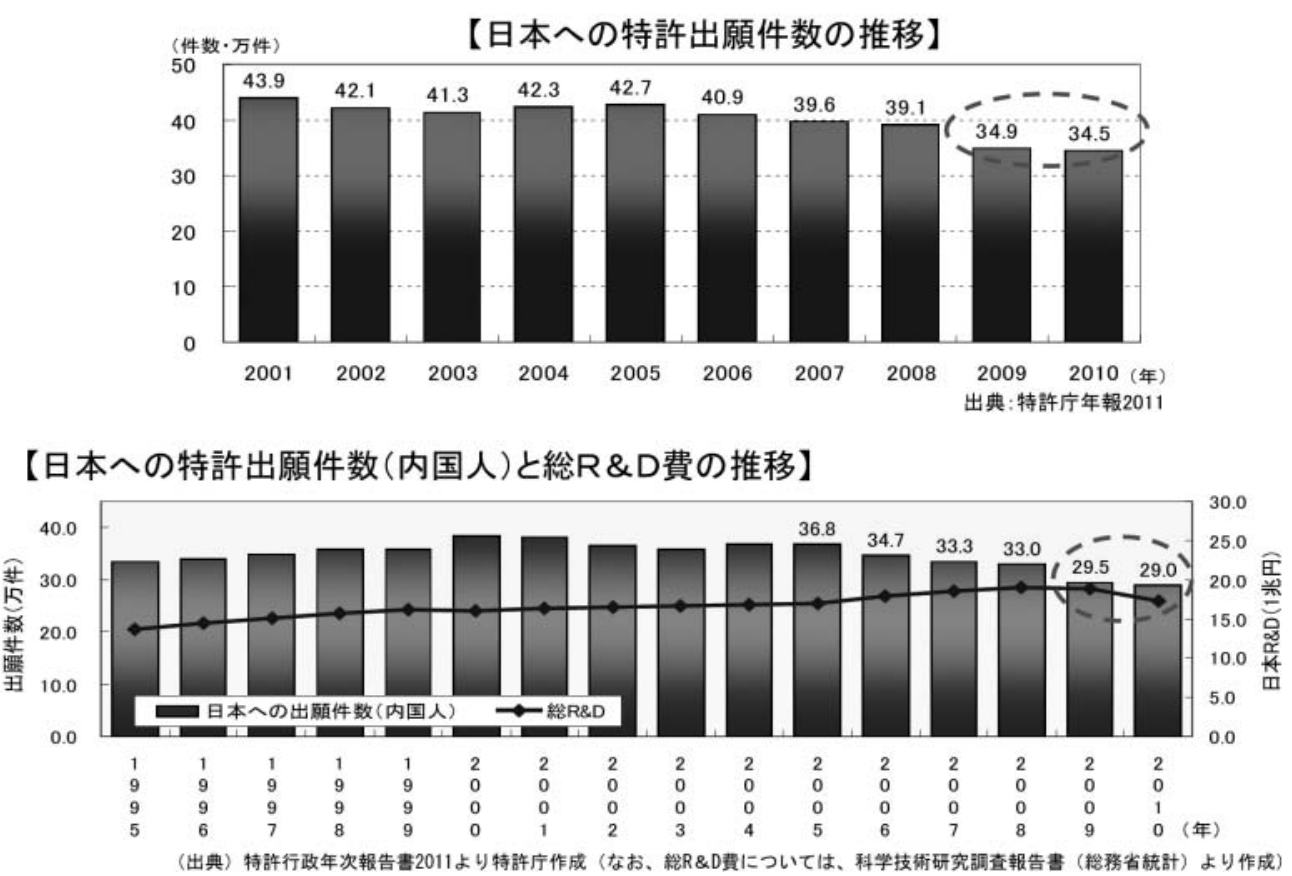

図 1 我が国への特許出願等と研究開発

です。

残念ながら参加できなかった方々はこれで情報を共有し ていただければと思います。また，本稿は，プレゼンテー ションをべースにしておりますが，国際的な部分を中心に 中身を充実させ，また読みやすく整理したつもりです。よ って，参加された会員の方々も一読いただければ，より確 かな理解が得られるのではないかと考えます。

\section{2. 我が国の特許出願・審査の現状}

\section{1 現状}

まず，最初に，我が国の特許出願・審査の現状からお話 しさせていただきます（図 1)。

日本への特許出願件数の推移ですが，40万件を超える 時代が長いこと続いておりましたが，ここ 2 年ほどは 35 万件前後となっています。2010年には中国に抜かれ，現 在世界第 3 位です。そして, その要因は内国人による出願 の減少といえます。

一方，総 R\&D 費の推移ですが，こちらの方は，2010 年 には少し減少が見られますが, 1995 年以降, 緩やかな右 肩上がりといえます。したがって，上述の出願の減少は， 必ずしも研究開発が停滞しているのではなく, 別の要因が あるのかもしれません。おそらく, 出願の厳選が進み, 量 から質へのシフトが進んでいるでしょうし，研究もより一 層中身の濃いものになっているのではないかと思います。

次に審査の現状ですが, 滞貨の解消は積年の課題でした が，おかげさまで近年はアウトプットがインプットを大き く上回っています（図 2)。また, 審査請求制度の改正に 伴う請求のコブもほぼ超えたため, 日本国特許庁（JPO）
における審査順番待ち期間（FA 期間）は，順調に短縮し ています。

2011 年度末には，FA 期間を 23 ヶ月未満とすることが 目標ですが，2012 年 1 月末現在で 23 ケ月台に突入してい るため，おそらく達成できるものと考えます。ちなみに当 室における FA 期間はおおよそ 20 ケ月程度（2012 年 1 月 末現在）であり，紙パルプ業界の皆様にもそれくらいのス ピード感で結果を提供しているのではないかと思います。

\section{2 審査の迅速化・効率化のための取組}

では, どうやってアウトプットを増強したのでしょう か? もちろん, 質を落として粗製乱造するわけにはいきま せん。審査の迅速化・効率化のために, 様々な取組が行わ れておりますが，代表的な 3 つの取組をご紹介させていた だきます。

\subsection{1審査官の増員}

一般に, アウトプットの増加のためにマンパワーの増強 と業務の効率化が重要な要素といえます。審査の世界も例 外ではありません。

ただ，審査の場合には，発明という高度な創作物を書面 上で理解し，様々な要件に照らし合わせて特許性の有無に ついて調査し, 判断し, その結果を文章で的確に伝え, さ らには出願人による補正や意見書での反論を考慮して最終 的な結論を導き出すという複雑なプロセスからなっていま す。また，落とし所がある場合には，審査の過程で補正の 示唆などによって積極的にそこに導いていくといった仕事 も求められています。こういった作業は, 経験を積んだ審 査官に頼らざるを得ないので，とりわけ，マンパワーの増 強が重要なポイントといえるでしょう。 
2010年度は、一次審査件数が審査請求件数を12万件以上上回り、審査順番待ち件数が減少。

審査順番待ち期間は短期化傾向に転じており、今後も短縮していく見込み。

○ 今後は、知財推進計画2004の長期目標 (2013年の審査順番待ち期間(FA期間)を11ヶ月に短縮)の

達成に向け、更に努力を継続。

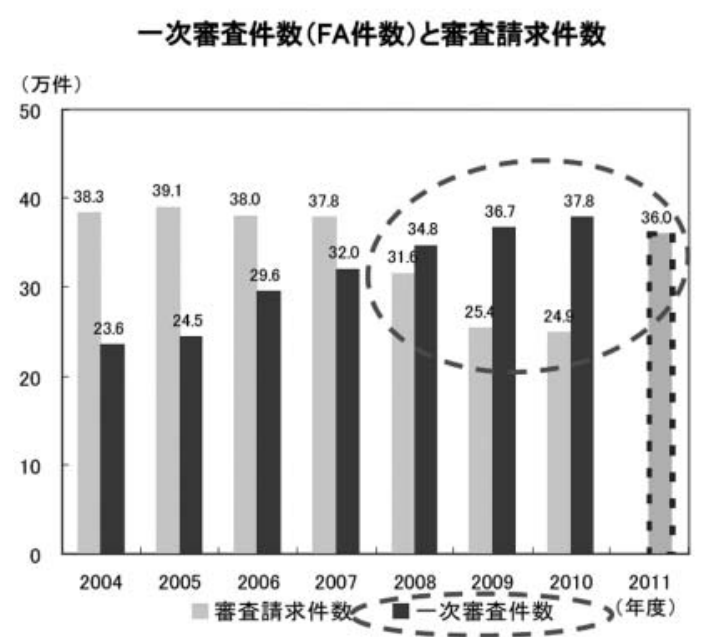

※2011年度の值は実施庁目標值
審査順番待ち件数(滞貨)と

寨查順番待ち期間(FA期間)

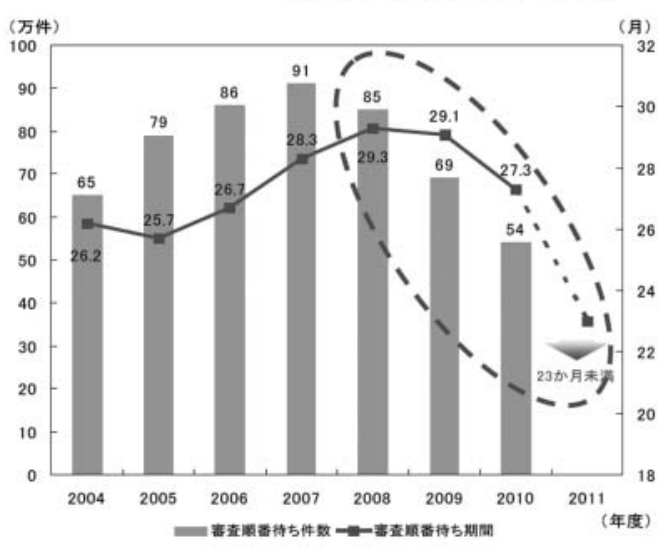

（四庁統計報告書より作成）

図 2 我が国の特許審査の現状

日本では公務員の増員は著しく困難ではありますが, 2004 9 年度にかけて 490 名の任期付き審査官の採用を行 い，特許審査官の数を 1,700 名ほどまでに増やすことがで きました。欧米に比べればまだまだ少ないですが，このマ ンパワーが処理の大きな原動力となっています。

\subsection{2 先行技術調査の外注を拡充}

もちろん, 効率化の部分も無視することはできません。 最も重要な施策が, アウトソーシング, すなわち先行技術 調査の外注です。

審査における判断や起案の部分は大変複雑高度な作業で あり，自前で責任を持ってやらざるを得ないですが，その 前の判断素材を提供するまでの過程については，多くの部 分を登録調査機関に依存しています。2010 年度において は 24.6 万件を外注し，そのうち 20.8 万件は対話型にして， 発明の理解と検索の部分の効率化を図りましたが，今年度 もそれとほぼ同レベルで外注を実施しています。

なお, 質の面を心配されるかもしれませんが, 登録調査 機関の調査業務実施者は, (独)工業所有権情報 ・研修館 (INPIT）の実施する研修をクリアした方々であり，採用後も 対話型審査などを活用した OJTを行っています。また, 調 査業務実施者がカバーしきれない点（例えば, 外国文献や 非特許文献のサーチ）は, 審査官が行っているので, ご安 心ください。

\subsection{3 国際的なワークシェアリング}

アウトソーシングと比べれば効果は限定的かもしれませ んが，国際的なワークシェアリングによる審査負担の軽減 も重要な取組といえます。日本の 35 万件の特許出願のう ち約 5.5 万件が外国からの出願であり, 日本の審査段階で 結果（あるいは経過）が出ている場合が少なからずありま す。そして, 欧州特許庁 (EPO), 米国特許商標庁 (USPTO) 及び韓国特許庁 (KIPO) の結果・経過については, ドシ
エアクセス・システム (包袋閲覧システム) ${ }^{1)}$ という審査情 報相互アクセスシステムで見ることができます。また，特 許審査ハイウェイ（PPH）を通じて情報が入ってくる場 合もあります。よって，これらサーチ/審査結果（あるい は経過）を最大限活用することによって，処理効率を高め ることが可能です。

なお，審査の効率化のために，これらのほかに，検索・ 起案システムの改良や地道な業務改善などを行っているこ とは言うまでもありません。

長期的な目標（といってももうだいぶ目の前に迫ってき ましたが）は，知財推進計画においても明示されているよ うに，2013 年に FA 期間を 11 ケ月に短縮することです。 こういった施策を通じて, 我々は今後も審査の迅速化・効 率化に取り組み，目標を達成する所存です。

\section{3. 世界の特許出願動向}

\section{1 世界的動向}

次に，視点を世界に向けてみたいと思います（図 3）。

経済のグローバル化を背景に，世界全体の特許出願は急 増しています。2008 年における全世界の特許出願件数は 190 万件と言われています。そして, そのうちの 4 割以上 が，非居住者による出願となっており，知財のグローバル 化が進んでいることが窅われます。

特に PCT の伸びが著しく，10 年前に比べて 2 倍近くと なっています。すなわち，単に海外に出願するだけではな く，多数の国を対象としたものが増えているわけです。世 界の市場あるいは生産ないし研究開発拠点が広がっている と考えられます。

\section{2 中国・新興国における動向}

伸びの背景には新興国への出願の急増があります。とり わけ，中国の動きを無視することはできません（図 4)。 
経済のグローバル化に伴い、

フこの10年で世界の特許出願件数は急増。特に、PCTルートによる特許出願件数が増加。

>全世界の特許出願件数約 191 万件 (2008年)のうち、外国へは約 84 万件(約 $44 \%$ )。

$>$ PCT加盟国数とPCT出願件数も急増。

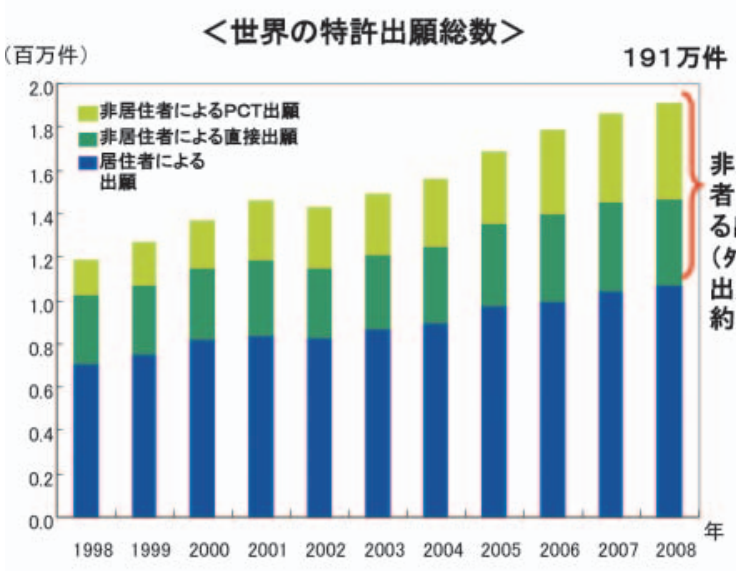

<PCT加盟国数及びPCT出願件数の推移〉

出風牪数:万件加盟国数

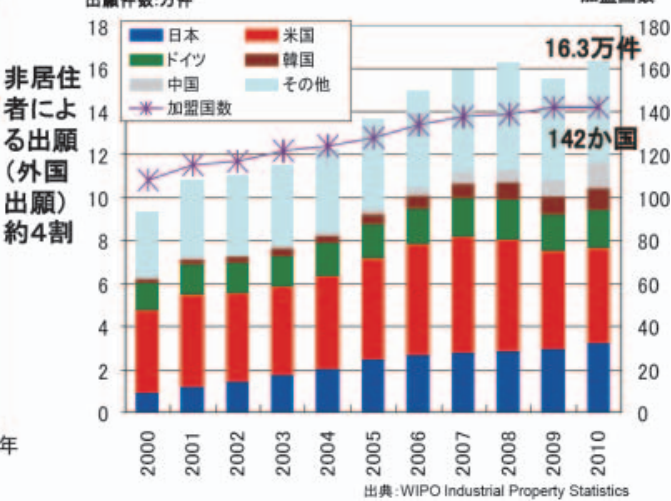

図 3 世界の特許出願動向

○中国における出願が急激に増加。内国人 (中国人)による出願が大幅に増加。

○ 非居住者の出願では、日本のシェアが最も多い(2010年)。

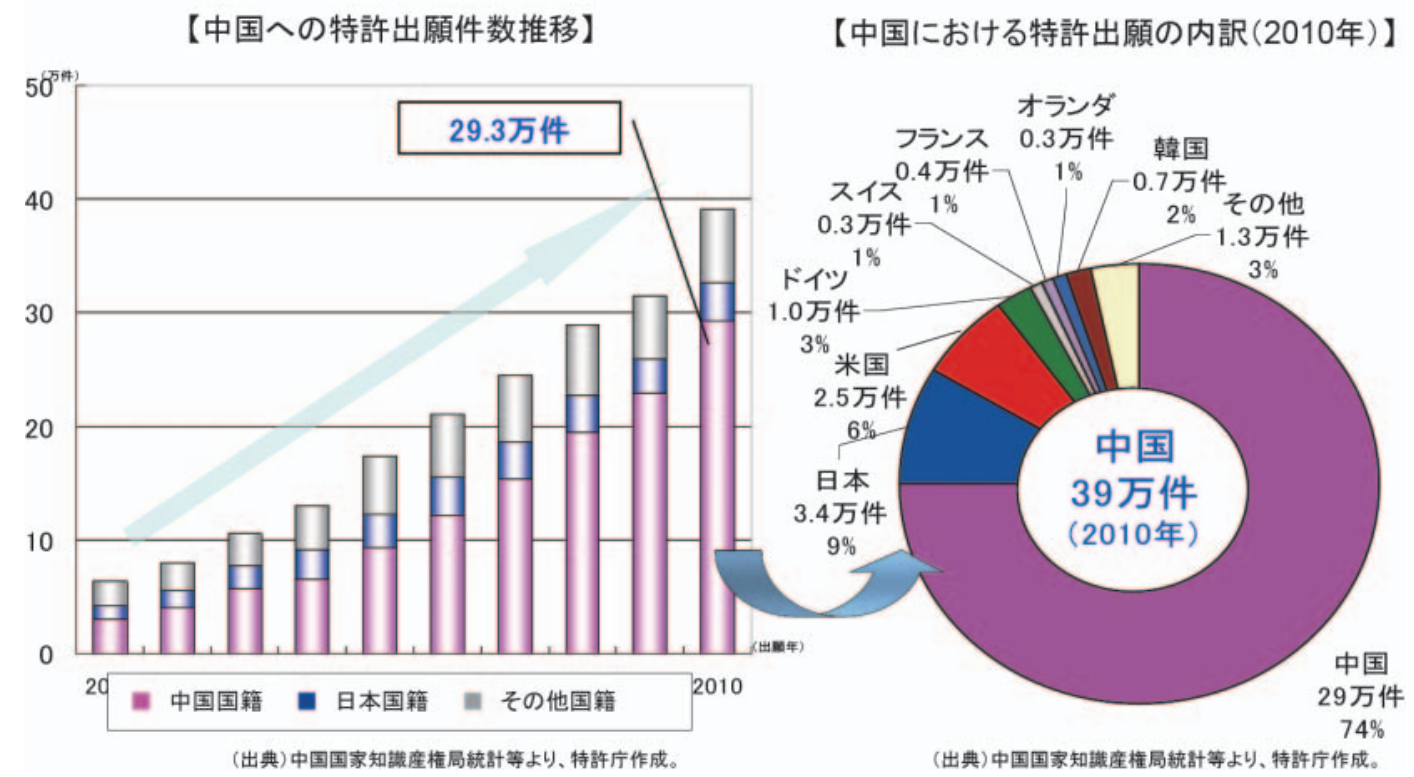

図 4 知財の世界でも中国企業の活動が活発化

2002 年まで中国国家知識財産局（SIPO）への出願は 10 万件未満でしたが，2010 年には 39 万件となり，ついに世 界第 2 位の出願大国となってしまいました。この出願急増 の背景には，国策により中国内国人による出願が大幅に増 加したことがあり，29 万件あまりを占めています。中国 は, 国策として出願を増やしているので, 出願は今後も伸 び続け， 2015 年には特許出願は現在の倍（約 75 万件）に 達すると言われています2)。

一方，非居住者による出願は，それほどではないですが，
着実に増えています。日本人の出願は 3.4 万件に上り，外 国人としては最も多い件数となっています。中国が，日本 の出願人にとって，マーケット的にも知財戦略的にも重要 な国であることは間違いないので，当然の結果といえるで しょう。

その他の新興国，いわゆる BRICsですが，中国とは枌 は違いますが,まだ数万件の出願レべルとなっています（図 5)。しかしながら, 欧米からの出願は大変多く, 彼らにと っては既に魅力的なマーケットとなっているのかもしれま 
○ 新興国(ブラジル、ロシア、インド)における日本からの特許出願のシェアは一桁程度。

○ 新興国(ブラジル、ロシア、インド)への出願は、日本よりも米からの出願の方が多い。
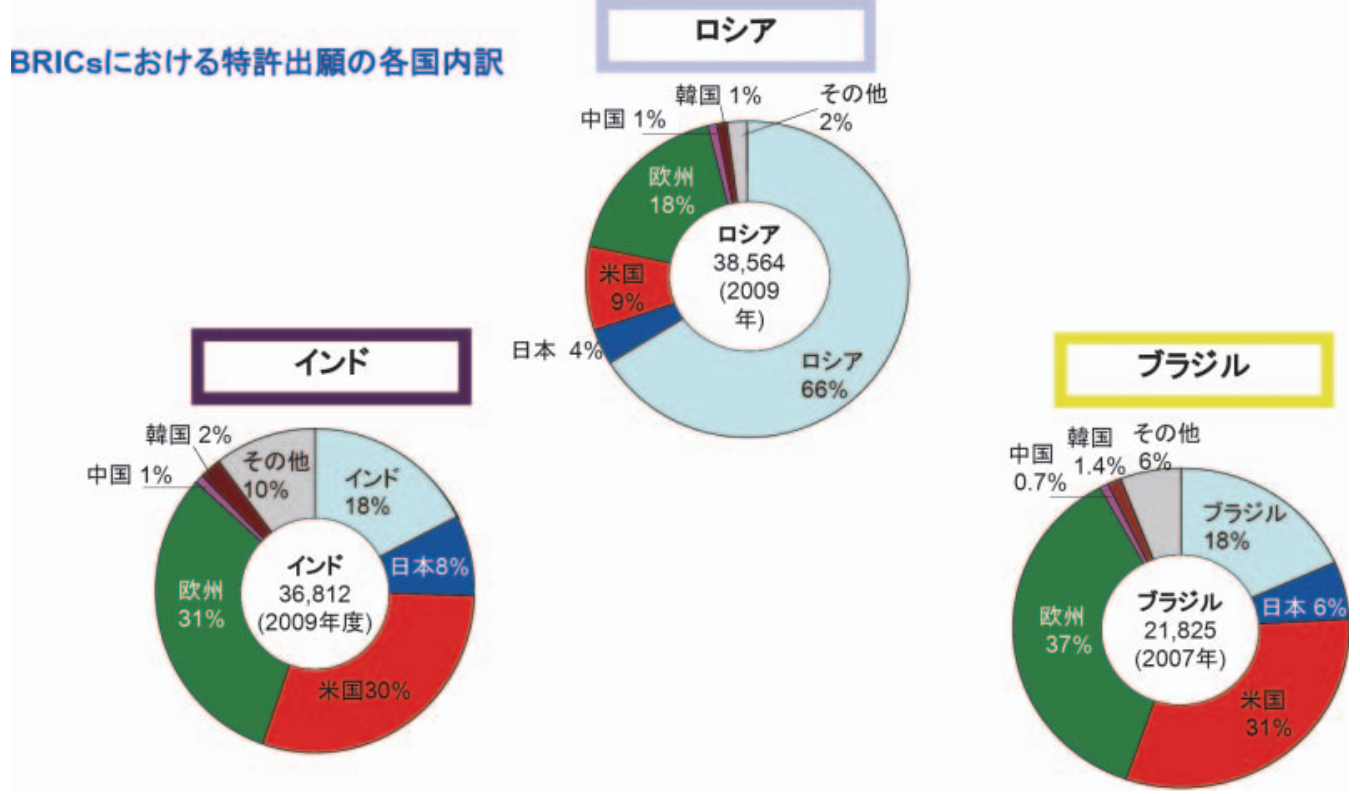

図 5 新興国における特許出願シェア

せん。一方，日本の占める割合は数\%程度であり，中国に 比べるとだいぶ出願の少ないことが分かります。まず中国 からと言うのはその通りなのですが，そろそろこれらの 国々にも目を向けないと, 市場に入り込むのが困難になっ てしまうかもしれません。

\section{4. 出願人の多様なニーズへの対応}

このような背景の中，出願人が我々に求める水準は高く なり，また多様化していると考えられます。それでは出願 人に対して何をしていくべきでしょうか?

一つは, いち早く権利を付与し, 国内外での事業や研究 開発を支援することでしょう。そのためには, 審査のスピー ドを上げ，迅速に権利を付与することが重要でありますが， それに対する取組は上記の通りです。ただ, 現時点でのス ピードではとても満足できない場合もあり，それに対する 答えも用意しておかなければなりません。

もう一つは，出願人にとっても第三者にとっても満足の いく安定した権利付与であります。質の高い審査は, 無用 な事後的紛争や出願競争を防ぎ，特許制度を健全に維持す るために欠かせないものです。これに関しても様々な取組 をしておりますが，情報や意見を受け入れる場を設けるこ とも取組の中に含まれているのではないかと思います。

さらには，時代にマッチングした変革も必要です。時代 にそぐわなくなった制度や審査基準は変えていかなければ ならないでしょう。

そして，別の側面から見た場合にグローバル化支援が非 常に重要なのですが，これは次章以下でご紹介致します。

それでは，出願人の多様なニーズへ対応するために特に 重要な施策を取り上げ，紹介させていただきます。

\section{1 早期審査制度 ${ }^{3)}$}

研究開発成果の早期活用やグローバルな経済活動等のた めに，できるだけ早く権利化を図りたいというニーズがあ りますが，このような出願に対して，審査処理期間は着実 に短縮しているものの，十分なスピード感を持って対応で きているとはいえません。そのため，実施関連，外国関連 など，早期の権利化が必要と考えられる特定の出願を対象 として，一定の要件を満たすことを条件に早期審査を実施 しています。この審査を行った場合, 早期審査の申請から 平均 1.7 ケ月で審査着手がなされます。

\section{2 スーパー早期審査制度}

中には，早期審査でもまだ遅いと感じられる方もいるか もしれません。そのニーズに応えるために，2008 年 10 月 より, 早期審査制度を拡充し，スーパー早期審査制度の試 行を行っています。スーパー早期審査制度においては, 重 要性の高い「実施関連」かつ「外国関連」を満たす出願を 対象として, 最終処分までの期間を大幅に短縮するため, 申請から一次審査までの期限を 1 ケ月以内，その後も応答 から 1 ケ月以内に着手しています。スーパー早期を利用し た場合, 申請から平均 25 日で審査着手がなされ, 平均 1.6 ケ月で最終処分に至ります(通常の早期では平均 5.5 ケ月)。 ただし，スーパー早期を利用するためには，オンライン手 続を行うこと, 出願人自身も 30 日以内に応答することが 求められますので, ご注意下さい。

\section{3 面接審 査 ${ }^{5}$}

審査は書面主義を原則としていますが，発明のポイント や先行技術との対比などは書面ではなかなか伝わらないこ とがありますし，一方，審査官の起案について確認したい 事項があるかもしれません。これをそのまま放置しておく 
と審査がうまく進まないばかりか，思いも寄らぬ結論に至 ってしまうことがあります。そのため, 審査官と出願人又 はその代理人との間において，円滑に意思疎通を図り，審 査手続の効率化に資するよう，面接審査を実施しています。 審査官と直接話をした方が迅速・的確な審査に資すると 考えられる場合, 面接審査（あるいは, 電話や FAX など これに準ずる手続）をご利用いただき，コミュニケーショ ンを図っていただければと思います。ただし，面接には一 定のルール（「面接ガイドライン」をご確認下さい）があ りますし, 迅速・的確な審査に資さないと考えられる場合 にはお受けできませんので，ご理解ください。

\section{4 情報提供制度 ${ }^{6}$}

審査には万全を期してはおりますが，実際には適切な引 用文献を探し出すことが困難な場合があります。特に, 周 知と思われるような事項に関してなかなか適切な文献が見 つからず，苦労することが良くあります。例えば，ライバ ル会社の特許出願に係る発明が, 新規性・進歩性を有して いない, あるいは, 記載要件を満たしていないなど, 審査 を行う上で有用な情報をお持ちの場合には，情報提供制度 がありますので，ご活用下さい。このような情報提供は， 審査を補完し, 迅速性・的確性の向上のために大変有用で あると考えています。

\section{5 特許審査の質の維持・向上}

面接審査や情報提供も質の高い審査のために重要ですが, オーソドックスな取組も多数行っています。

1 つの取組は，厳しすぎる判断や判断のバラツキの防止， 最高裁判決との整合性などの点からの審査基準の改訂であ $り$, 今年度も「明細書及び特許請求の範囲の記載要件」,「特 許権存続期間の延長」に関する審査基準の改訂 ${ }^{7}$ が行われ, 公表されました。また, 法改正への対応や出願人ニーズな どを受けて, 新規性賈失の例外規定の適用やシフト補正に 関しての審査ハンドブックの改訂なども行っています。

もう一つの取組としては, 品質監理の強化があります。 2007 年 4 月には品質監理室及び品質監理委員会が設置さ れ, 個別の案件の審査の「品質管理」と技術横断的な「品 質監理」が行われています。具体的には, 個別の案件につ いて, 管理職によるチェックを行うほか, 重要な案件に関 しての複数審査官による協議, サンプルチェックを行い, 的確な審査と判断基準の統一的運用がなされるよう務めて います。また, チェックした結果やユーザーの意見などを 統計情報としてまとめ, 分析を行い, その結果を質の改善 施策の検討やフィードバックに活用しています。

品質監理の強化は，JPO だけにとどまるものではあり ません。国際的なワークシェアリングの推進やグローバル な特許保護のためには, 各国・機関の特許庁が足並みを揃 えて行かなければなりません。そのため, 日米欧三国特許 庁会合や日米欧中韓の五大特許庁会合においても活発な議 論が展開されています。

\section{6 特許法の改正 ${ }^{8)}$}

知的財産制度を取り巻く環境は常に変化しており, それ に的確に対応するため, 時として法改正を行うことが必要 です。今年度もオープンイノベーションの進展などに対応
するため，ライセンス契約の保護の強化（当然対抗措置の 導入), 共同研究 - 共同開発の成果の適切な保護（冒人出 願に対する特許権等の返還請求制度導入), ユーザーの利 便性向上（減免期間の延長，新規性喪失の例外規定の適用 範囲拡大など), 紛争の迅速・効率的な解決のための審判 制度の見直しなどの改正が行われました。制度改正につい ての説明会は終了してしまいましたが，テキストは特許庁 HP からダウンロードできるので，ご活用下さい。

\section{5. 特許審査ハイウェイ $(\mathrm{PPH})^{9)}$}

\section{1 概 要}

上記 3 の説明からも明らかなように, 知財のグローバル 化は大きく進んでいます。これに対応するため, 我々特許 庁は色々な形で支援をしていかなければなりません。これ までも，企業のグローバル化支援施策を打ち出しており， その集大成が，後にお話をする国際知財戦略ですが，ここ では今一番トレンディーな特許審査ハイウェイ（PPH）に ついてお話をさせていただきます。

特許審査ハイウェイとは, 第 1 庁または PCT 国際段階 で特許可能と判断なされた出願（特許可能と判断されたク レーム有する場合も含む) について, 出願人の申請により, 第 2 庁または PCT 国内段階において早期審査を受けられ るシステムです（図6）。

ユーザーの立場から見れば，(1)重要な出願を世界各国に おいてほぼ同じ夕イミングで権利化することができる，(2) 第 2 庁においては第 1 庁における審査/サーチ結果をべー スにして審査が行われるので, 無駄な拒絶理由が通知され ることなく，時間とコストの節約ができる，といったメリ ットがあります。

経済のグローバル化に伴い, 日本のみならず，海外でも 早期に権利化を図りたいというニーズが高まっていると思 われます。その場合には，早期審査あるいはスーパー早期 審査を活用して，まず日本で権利を取得し，それをもって 外国で PPH を申請し, 主要国でいち早く権利化を図ると いう手法を取ることができます。

また, 特許庁の立場から見れば, (1)第 1 庁の結果を最大 限活用することで, 重複した審查/サーチを避け, 審査負 担の軽減を図ることができる，(2)第 1 庁の結果とのベスト ミックスや第 2 庁からの結果のフィードバックで質の向上 が期待できる，といったメリットがあります。また，審査 負担の軽減（審査の効率化）と質の向上は, 結局は出願人 にとってのメリットでもあるといえます。

\section{$5.2 \mathrm{PPH}$ の発展とネットワーク形成}

余談ですが，実は特許審査ハイウェイは日本国特許庁の 発明です。また，私自身が立ち上げ時に交渉の担当者（審 查企画室長）として哚く関わらせていただき，アメリカと の試行開始（2006 年 7 月 3 日）という歴史的瞬間に立ち 会わせていただきました。しかし，その道のりは平坦なも のではなく, 2005 年 11 月の三極特許庁会合で提案したと きの議長国の $\mathrm{EPO}$ の反応は大変冷ややかなものでした。 初期の $\mathrm{PPH}$ は, 第 1 庁主義に基づく審査負担の軽減と早 期審査の申請負担の軽減が一番の売りであったため, 滞貨 


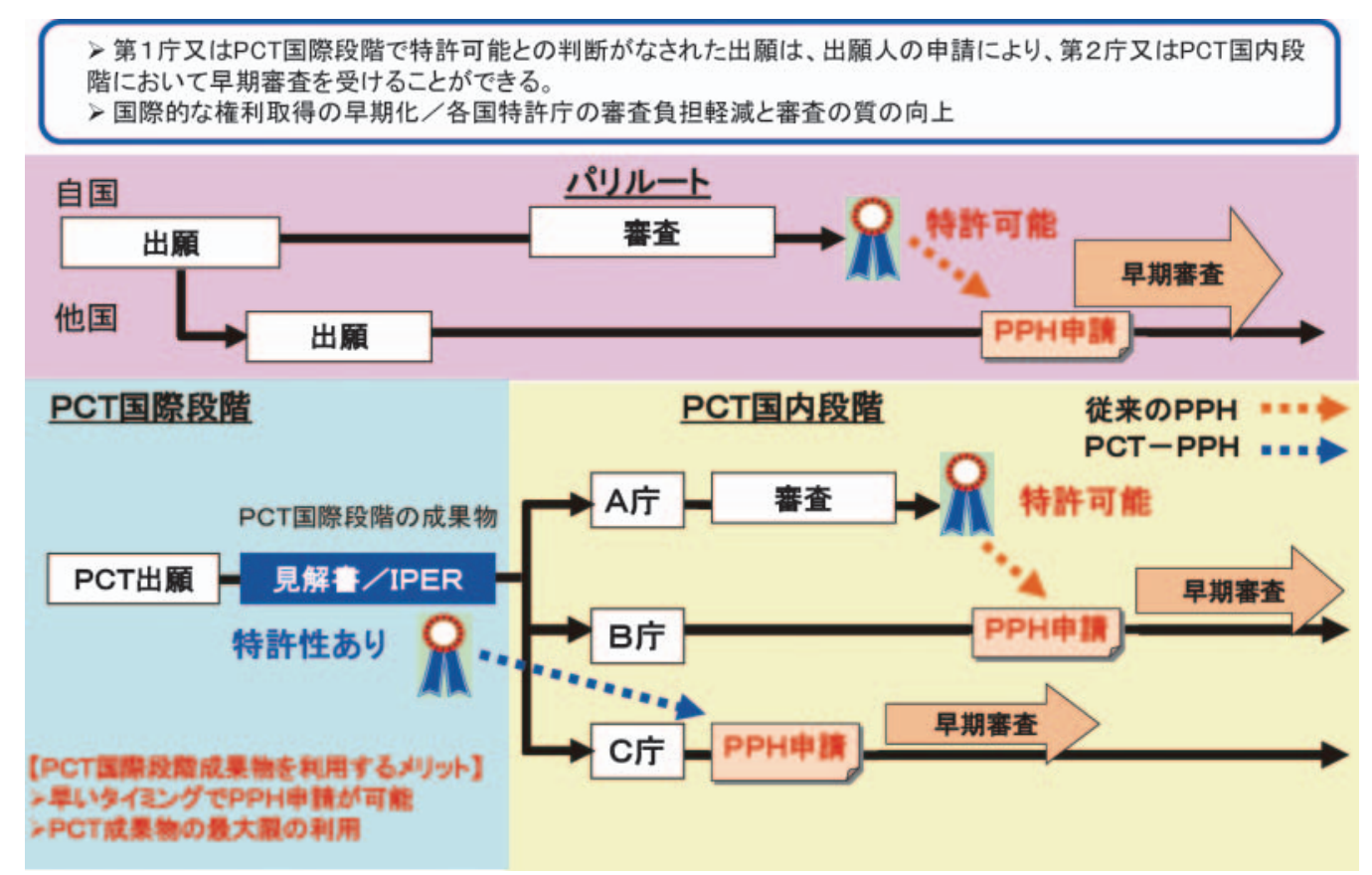

図 6 特許審査ハイウェイ（Patent Prosecution Highway：PPH）

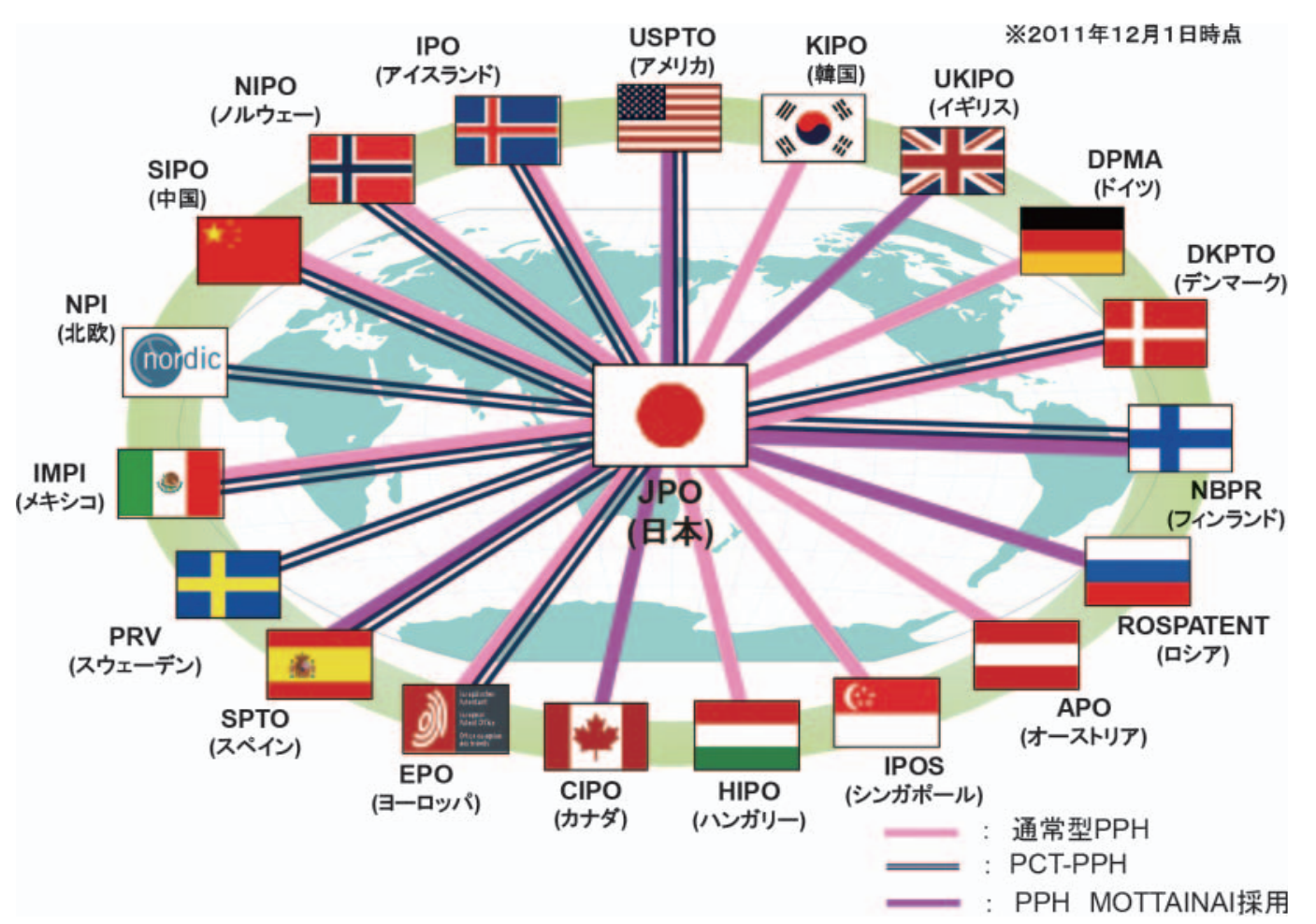

図 7 PPH ネットワーク

が深刻でなく，常にサーチレポートを発行し，早期審査も ほぼ無条件で受け入れている彼らにとって見れば，メリッ トが見えにくかった様です。また，審査負担軽減効果の小 さい PCT は対象外としていたことや, 別の政策としてニ ユー・ルート（少数の国に出願する場合にパリルートとも PCT ルートとも別の道を開く制度 ${ }^{10)}$ を提案していたこと などから, PCT 制度へのチャレンジと映ったようです。お かげで，合意どころか，議事録から提案そのものが削除さ
れそうになったのですが，USPTO と JPO との利害が一 致し，その場で試行を検討するところまで合意したため, 大きな一歩を踏み出すことができました。

そして, その後, 特許審査ハイウェイは大きな進化を遂 げ，試行とはいえ EPO も参加させ，巨大なネットワーク （日本を軸として場合，2012 年 2 月時点で 17 力国・2 機関 と実施）が構築されています（図 7)。重要な出願を世界 各国においてほぼ同じタイミングで権利化することができ 
>従来のPPHでは、原則、第一庁 (出願人が最先に特許出願をした国)の審査結果に基づく申請の みしか認められていなかったが、本試行プログラムにおいては、出願人がどの国へ最先に特許出 願をしたかによらず、参加国による特許可能との審査結果に基づき、申請が可能。 2011年7月15日から 1 年間の予定で試行。

\section{本試行プログラムの開始により、新たにPPH申請が可能となるケース}

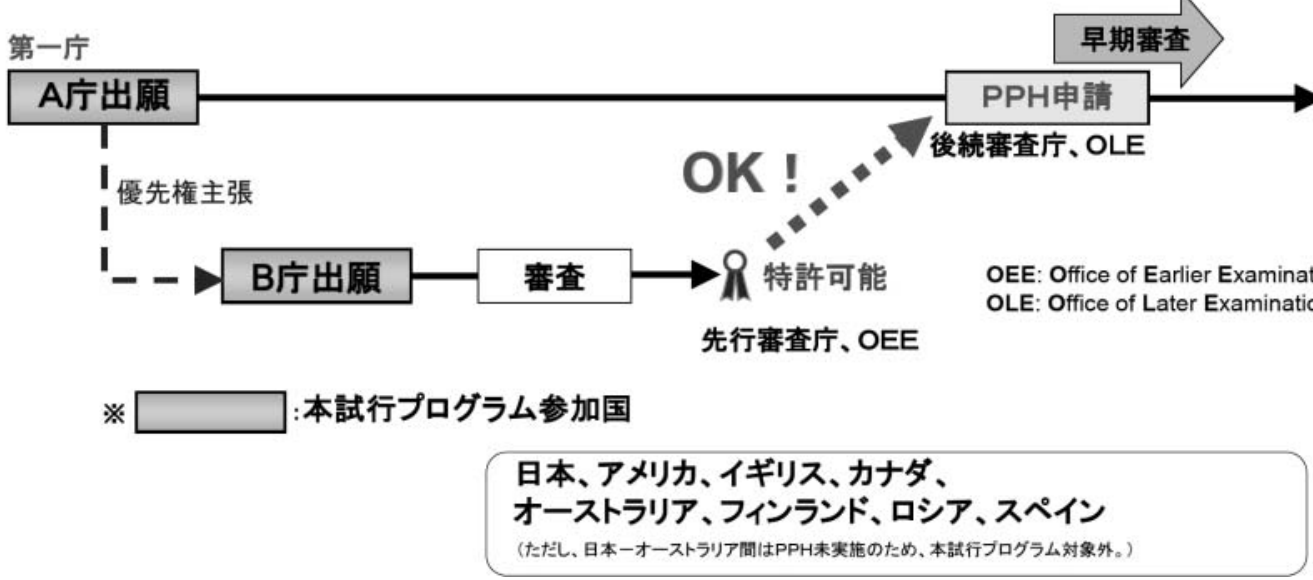

図 8 申請要件を緩和したPPH 試行プログラム「PPH MOTTAINAI」

るという観点から見れば，このように多数の国・機関が参 加していると言うことは非常に重要なことといえます。

\section{$5.3 \mathrm{PPH}$ の今後の課題}

しかしながら，特許審査ハイウェイはまだ進化の途中で す。新たな試みとして, PPH・MOTTAINAI が 2011 年 7 月 15 日から試行をされています（図 8)。PPH の原点は審 査負担の軽減であるため, 第 1 庁（出願人が最先に特許出 願をした国）が責任を持って最初の審査結果を発信するこ とを原則としています。通常，最初に出願した国にその関 連技術が多く存在し，よって引用文献が出てくる確率が高 いこと，他庁はその最も確からしい結果を活用できること などから, 大変メリットが大きいといえます。けれども, ユーザーにとっては第 1 庁の審査結果に基づく申請しか認 めらないので，仮にどこかの庁で迅速かつ的確な審査の元 に特許になっていても特許審査ハイウェイを利用できない というデメリットがあります。これだけネットワークが大 きくなるとその弊害は大きいといえます。PPH・MOTTAINAIでは, 出願人がどの国へ最先に特許出願をした かによらず，その参加国による特許可能との審査結果に基 づき，申請が可能である。もし，このメリットの方がデメ リットを上回るという結果が出れば，本格実施へ移行し， また参加国も増えていくことでしょう。

また，特許審査ハイウェイは，基本的にバイで結ばれた ネットワークであるので，基本コンセプトは同じとはいえ， 各々の仕組みは微妙に異なっています。この点を完全に解 決するためには，制度自体のハーモナイゼーションが必要 ですが，現実的な範囲内で土俵をできる限り同じにしてい くことが必要と考えられます。

さらに，中国以外の新興国（インド，ASEAN 等）など, 参加国をできる限り増やしていくことも大きな課題です。
本年 2 月 9 日に開かれたJPO とフィリピン知的財産庁と の長官会合で，3 月 12 日から試行を開始することに両庁 は合意しました。これはまだ第一歩ですが，PPH ネット ワークの更なる広がりが大いに期待されるところです。

\section{6. 我が国の「国際知財戦略 $]^{11)}$}

\section{1 世界で通用する安定した権利のために}

知財のグローバル化への対応のため, 我々はさらに大き な課題に取り組もうとしています。国際知財戦略の策定で す（図 9)。

グローバルな事業展開には海外で安定した経済活動が保 証されるよう，安定した権利保護が必要です。そのために は, 日本の結果が世界でそのまま受け入れられる土壤を作 っていかなければなりません。特許審査ハイウェイ及びド シエアクセシステムは, 日本のサーチ/審査結果を発信し, これを推進するための重要な役割を担っているといえるで しょう。

また，最終的には特許制度のハーモナイゼーションが必 要です。昨年, 米国特許制度が改正され, ハーモナイゼー ションの機運は一気に高まり，日米欧中韓五庁による真剣 な議論が行われています。しかし，これまでの道のりを見 て，簡単には実現できないかもしれません。

そこで, 日本単独あるいは主導で進められることは, ハー モナイゼーションと並行してどんどん進めていかなければ ならないわけです。まずは，特許審査の質を更に向上させ， 日本の審査が真に国際標準となるためのインフラ整備を図 ることが重要ですが，そのための課題は以下の 3 つです。

6.2 国際知財戦略構築に向けて

6.2.1 外国特許文献検索システムの開発

1 つには，外国特許文献検索システムの開発です。もち 
○グローバルな事業展開には海外で安定した経済活動が保証されるよう、安定した権利保護が重要。

○そのためには、我が国の特許審査の質を向上させ、権利の安定性を高め、日本の特許が速やかに 世界で受け入れられる環境の構築を推進 。

外国特吘文献検索システムの開毠

○機械翻訳（中ー日、韓 $\rightarrow$ 日など）

を利用した外国特許文献 DBの構築

\section{共通特許分類の策定}

O日欧の分類を軸に、五庁・W I P Oで共通特許分類を策定
グローパル化に対応した㥶查体制

○審査体制の強化 (人的体制・研修) ○世界水準の品質監理の実施

\section{世界標準となる安定した権利付与}

\section{国際的な特許制度の調和を目指す}

図 9 国際的な特許制度の調和への道筋

ろん，現在でも，特許庁は世界の文献を検索するためのシ ステムを有しており，とりわけ，日本の特許文献や世界の 主要ジャーナルを検索するツールは大変充実しています。 また，欧米の特許文献検索に関してもかなり満足のいくも のが用意されています。

しかしながら，中国や韓国での出願急増などに伴い，今 や日本語で読める特許文献は $24 \%$ と言われていますし, 英 語を入れても半分に満たない状況です。一方，中国語や韓 国語でしか読めない文献は $39 \%$ を占め，特に中国語特許 文献に関しては, 今後, 益々比率が高まっていくと予想さ れます。また，現時点では，中国語や韓国語の特許文献が 先行技術として必ずしも有用でないケースが多いですが, 将来的には極めて重要なものとなっていくと考えられます。 現在でも検索は可能ではありますが，充実したシステム とはいえないでしょう。中韓の特許文献を十分かつ効率的 な検索を行うためには，自動翻訳の技術を活用し，日本語 でも検索し, 表示させるといった機能を開発する必要があ ると考えます。また, 次に述べる共通分類の構築も必要で す。

\subsection{2 共通特許分類の策定}

2 つめは, 共通特許分類の策定です。IPC という国際特 許分類があり，世界の特許文献に付与されておりますが， 世界のどの国・機関でも付与できるようにするために，一 般的にはシンプルです。これは，裏を返せば先行技術調査 には必ずしも満足の行くものではないということです。こ の問題を解消すべく，10 年ほど前から日米欧三極で共通 分類を作成し，それを新たな IPC とすべく提案していく というプロジェクトを行っています。

しかしながら，(1)プロジェクトの進展が遅く，ごく限ら れた分野でしか作成できていない（理由は多々あるのです
が，大変長くなるので省略いたします)，(2)採用されたも のも全ての国・機関で付与されるものではない（コアとア ドバンストという二重構造になっており，三極で提案した ものは一部の国・機関で使用されるアドバンストという形 で採用されていました)，(3)中国，韓国などの影響力が無 視できず，三極だけではプロジェクトをリードできない， といった問題を抱えていました。

そのため, 現在では, (1)既に細分化されている FIや ECLA を最大限活用し，これのハイブリッド型とするこ とによって，プロジェクトの進展を加速する，(2)コアとア ドバンストという二重構造を廃止し，IPCを一体化する， (3)日米欧中韓の五庁でプロジェクトを進める, といった改 革を行いました。また，JPOは，本年度，FI と ECLA と の比較検討を行い，FI と ECLA とをべースとするハイブ リッド分類作成のための基礎資料を作成し，プロジェクト の加速を呼びかけています。

このプロジェクトが完成すれば，どの技術分野において も，IPC を使って世界の特許文献をかなり絞り込むことが でき，充実したサーチが可能となります。

\subsection{3 グローバル化に対応した審査体制}

3 つめは，グローバル化に対応した審査体制の整備です。 これについては, 上記 4.5 で述べたとおりですが, 日本の 審査を国際水準に合わせ，またその品質の高さを理解して もらうためには，国際審査官協議といった取り組みも重要 であると考えます。

\section{3 紙パルプ業界の国際知財戦略}

これは我々の考えている構想でありますが，ユーザーサ イドの視点を入れて，日本の産業の発展に寄与するような 素晴らしい戦略に仕上げて生きたいと思います。そして, 特許庁だけではなく，ユーザーの国際知財戦略をサポート 


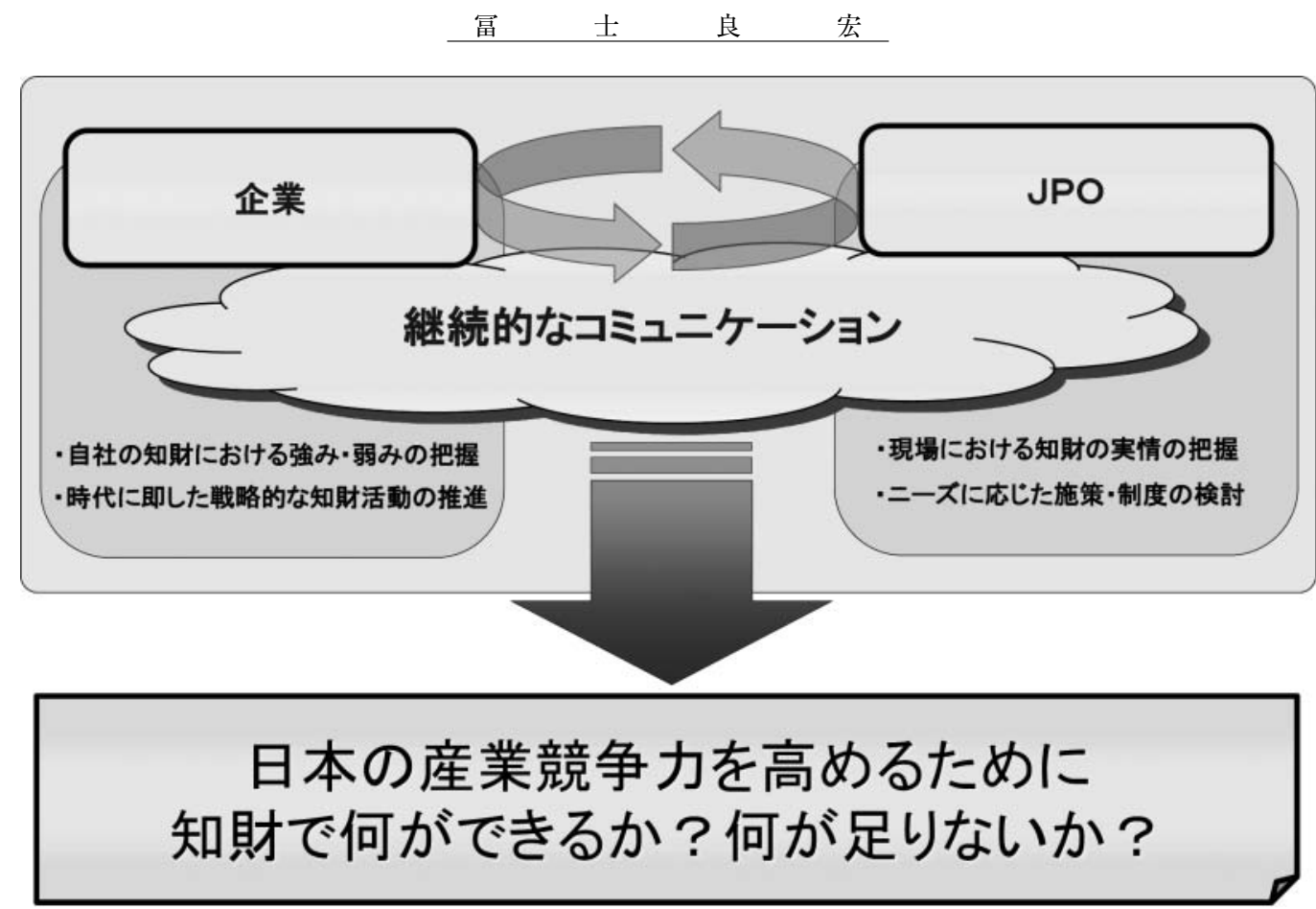

図 10 今後に向けて

していくという視点も必要でしょう。例えば，中国特許文 献の検索ツールは, 日本の出願人にとっても大変有用で, 待ち望んでいるものです。民業圧迫にならない範囲でとの 制約はあるでしょうが，良いツールを作って，外部に提供 し，ユーザーの国際知財戦略に役立てるという視点も重要 と考えられます。

ちなみに, 紙パルプ業界のグローバル出願率は，ここ数 年， $10 \sim 15 \%$ 程度（2010 年の日本の出願人平均は $25 \%$ 程 度）です。また, PCT の出願件数は 60 件程度（出願比率 $5 \sim 6 \% ; 2010$ 年の日本の出願人の平均出願比率は約 $9 \%$ ）であり，低めになっています。このように，紙・パ ルプ業界は，統計的に見て，国内に閉じた出願の割合が高 いようです。私の同僚からは技術が素晴らしすぎて逆に海 外ではオーバースペックになって売れない，国内市場だけ でも十分な売り上げがあるので外に目を向けないといった 話を良く聞かされています。

しかしながら，国内市場は飽和しており，さらには中国 など海外からの輸入が増加しており, 今後国内需要の拡大 は難しいかもしれません。一方で, 新興国での大幅な需要 拡大が見込まれています。実際，意見交換会で㧍話をした ところ, 不景気の影響もあり, 事業の縮小や転換, 果てに は出願費用などの知財コストの削減を迫られている反面, 海外での事業の拡大や知財戦略を模索している企業も多い ようです。日本の紙パルプの技術は大変素晴らしいもので あり, 数千億から 1 兆円規模の世界トップクラスの売り上 げを有する企業が何社もございます。誰でも品質の良いも のを欲しており，ビジネスモデルの工夫次第で，いくらで も海外市場への参入の余地はあるのではないかと考えます。

したがって，厳しい環境にあることは事実ですが，今こ そ, 海外での知財戦略に真剣に取り組む時期といえるかも しれません。意見交換会に扔いても，中国を中心に，海外
における審査レベルの向上, エンフォースメントの改善, 外国特許文献検索ツールの外部提供など, 様々な意見, 要 望をいただきました。我々は，今後とも，紙パルプ業界の 皆様と，我が国としての国際知財戦略，そして業界あるい は企業としての国際知財戦略を一緒に考えていければと思 います。

\section{7.おわりに}

我々審査官の仕事は，迅速的確な審査を行うことであり ます。そのためには，その業界において，技術水準がどの レベルにあり，どのような権利保護が求めているのかを常 に認識しておく必要があるのですが，残念ながら，普段の 仕事からは生きた情報が入ってきません。また，ユーザー にとって現状の審査が満足行くものであるのか, 問題があ るのであればどのような点を改善する必要があるのかなど も把握しておかなければなりません。

一方，特許行政に身を置くものとして，特許を取り巻く 環境やそれに対する取組をユーザーへ情報発信し，より良 い知財戦略構築に活用していただく使命がございます。さ らに，我々の施策や審査への取組に対してご意見・ご要望 をいただき，今後の制度設計と業務改善につなげていかな ければなりません。

この点，紙パルプ技術協会との意見交換会は，この分野 における主要企業の知財の最先端におられる方々とが，直 接㧍話をする機会を提供するものですから，必要な情報を 発信し，収集する場として最適といえます（図 10）。

このように大変有意義な意見交換会を今後とも継続実施 し，双方にとって益々実りあるものとしていければと思い ます。

\section{References}

1）杉山輝和，「サーチ・審査結果の相互利用の本格化に 
向けて」，特技墾，No.244，p. 36-44（2007）

(http : //www.tokugikon.jp/gikonshi/244toku2-1. pdf)

2) JETRO 北京事務所知的財産権部 知財ニュース, 2011/4/1 号, (No. 148)

(http : //www.jetro-pkip.org/upload_file/201104014 9548937.pdf)

3）日本国特許庁 HP，「特許出願の早期審査・早期審理 について」

(http : //www.jpo.go.jp/torikumi/t_torikumi/souki/ v3souki.htm)

4）日本国特許庁 HP，「スーパー早期審査の試行開始に ついて」

(http : //www.jpo.go.jp/torikumi/t_torikumi/souki/ supersoukisinsa.htm)

5）日本国特許庁 HP，「面接ガイドライン【特許審査編】」 (http : //www.jpo.go.jp/shiryou/kijun/kijun2/men setu_guide_index.htm)

6）日本国特許庁 HP，「情報提供制度について」

(http : //www.jpo.go.jp/seido/s_tokkyo/tt1210-037_ sanko2.htm)
7）日本国特許庁 HP，「審査基準の追加・改訂について」 (http : //www.jpo.go.jp/shiryou/kijun/kijun2/pu-ki jun_kaitei.htm)

8）日本国特許庁 HP,「特許法等の一部を改正する法律 (平成 23 年 6 月 8 日法律第 63 号)」

(http : //www.jpo.go.jp/torikumi/kaisei/kaisei2/tok kyohoutou_kaiei_230608.htm)

9）日本国特許庁 HP，「特許審査ハイウェイについて」 (http : //www.jpo.go.jp/torikumi/t_torikumi/patent _highway.htm)

10）杉山輝和，「サーチ・審査結果の相互利用の本格化に 向けて」，特技墾，No.244, p. 36-44（2007）

(http : //www.tokugikon.jp/gikonshi/244toku2-1. pdf)

11）日本国特許庁 HP，「産業構造審議会第 16 回知的財産 政策部会 資料 1 「国際知財戦略 (Global IP Initiative) 〜国際的な知的財産のインフラ整備に向けた具体的方 策」」

http : //www.jpo.go.jp/shiryou/toushin/shingikai/ pdf/tizai_bukai_16_paper/siryou_01.pdf 